\title{
MANAJEMEN INOVASI PENDIDIKAN KARAKTER PADA MASA PANDEMI COVID-19
}

\section{MANAGEMENT OF CHARACTER EDUCATION INNOVATIONS DURING THE COVID-19}

\author{
DEDE ROHMAT
}

SDIT Nurul Fikri Depok

Received: March 04, 2021
Revised: March 07, 2021
Accepted: March 12, 2021

\begin{abstract}
The condition of the character education learning model during the pandemic will certainly be different from the process of cultivating character by direct learning at Schools. The objective of this research is to analyse Character Education Innovation Management process, obstacle, what solution can be given, and to analyse the behavioural implication which is formed from implementation endeavour of character education innovation during the Covid-19 pandemic at SDIT Nurul Fikri.The result of this research indicates character value which developed by SDIT Nurul Fikri is SMART character. The Management of Character Education Innovation at SDIT Nurul Fikri apply POAC model or approach. The result of this research also indicates the implementation of Character Education Innovation Management functions during Covid-19 pandemic at SDIT Nurul Fikri has a positive impact on the development of SMART's student character
\end{abstract} penanaman karakter dalam kondisi pembelajaran secara langsung. Sekolah harus melakukan berbagai inovasi sehingga dalam pelaksanaannya pendidikan karakter tetap terlaksana dengan optimal walaupun saat pandemi. Tujuan penelitian ini adalah untuk menganalisis proses manajemen inovasi pendidikan karakter, kendala, solusi serta menganalisis implikasi prilaku yang terbentuk dari upaya pelaksanaan inovasi pendidikan karakter pada masa pandemi Covid-19 di SDIT Nurul Fikri. Metode dalam penelitian ini menggunakan jenis dan pendekatan mix methods dengan strategi exploratory sekuensial. Sumber data ada dua macam yaitu sumber data primer dengan wawancara, angket dan observasi dan sumber data sekunder didapatkan dari dokumen yang berkaitan dengan penelitian yang dilakukan. Hasil penelitian ini menunjukan bahwa nilai karakter yang dikembangkan di SDIT Nurul Fikri adalah karakter SMART yaitu sholeh, muslih, cerdas, mandiri dan terampil yang merupakan salah satu program unggulan sekolah. Manajemen inovasi pendidikan karakter di SDIT Nurul Fikri menggunakan pendekatan POAC. Perencanaan pengembangan karakter masa pandemi adalah mengarah kepada penetapan tujuan yang hendak dicapai dan perumusan program pendidikan. Proses pengorganisasian meliputi penetapan jadwal pelajaran, jadwal pelaksanaan program pendidikan karakter serta penetapan penanggung jawab kegiatan. Proses actuating yaitu pelaksanaan pendidikan karakter melalui pembelajaran, Ekstrakurikuler dan pembiasaan. Proses controlling yaitu pengawasan yang terintegrasi dengan supervisi sedangkan pengawasan pendidikan karakter melalui ekstrakurikuler dan pembiasaan dilakukan dengan form mutaba'ah dan evaluasi kegiatan yang diisi oleh siswa dan orang tua. Hasil penelitian menunjukan bahwa Implementasi fungsi-fungsi manajemen inovasi pendidikan karakter pada masa pandemi di SDIT Nurul Fikri berdampak positif terhadap perkembangan karakter SMART siswa

Keywords: Management, Character Education, Educational Innovation, Covid-19

Kata kunci: $\quad$ Manajeman, Pendidikan Karakter, Inovasi Pendidikan, Covid-19

(*) Corresponding Author: dede.rohmat@nurulfikri.sch.id

How to Cite: Rohmat, D. (2021). Manajemen Inovasi Pendidikan Karakter Pada Masa Pandemi Covid-19. Jurnal Lingkar Mutu Pendidikan, 18 (1), 41-52. https://doi.org/10.54124/jlmp.v18i1.16

\section{PENDAHULUAN}

Fenomena yang menunjukan degradasi karakter telah banyak kita jumpai dalam kehidupan seperti peristiwa kekerasan dan tawuran, pemerkosaan, minuman keras dan penggunaan narkoba, pelecehan dan seks bebas, pelanggaran lalu lintas, mengotori dan merusak fasilitas umum, penganiayaan hingga pembunuhan. Karakter jujur, sopan santun, tenggang rasa, toleransi, solidaritas, dan kepedulian sosial 
sudah menjadi sikap yang sulit kita temukan di tengah kehidupan remaja. Redesain sistem pendidikan karakter merupakan sebuah keharusan dalam upaya memperbaiki degradasi karakter remaja.

Sebagai salah satu tujuan dan cita-cita pendidikan Nasional yang terdapat dalam UndangUndang Sisdiknas Nomer 20 tahun 2003 pasal 3 tentang pendidikan karakter maka pemerintah terus berupaya meningkatkan kualitas pendidikan karakter melalui berbagai macam kebijakan satunya melalui Peraturan Presiden Nomor 87 tahun 2017 tentang Penguatan Pendidikan Karakter (PPK). Dalam Nawacita Nomor 8 telah diamanatkan Gerakan Nasional Revolusi Mental (GNRM) dimana PPK merupakan bagian dari GNRM tersebut.

Pendidikan karakter merupakan program pemerintah yang diharapkan menjadi solusi terhadap berbagai macam fenomena degradasi karakter yang terjadi di tengah masyarakat Indonesia. Program pendidikan karakter tersebut adalah berlandaskan Falsafah Pancasila, UUD 1945 yang bersumber inti pada Al-Qur'an dan hadis Nabi Muhammad saw., sebagai tolak ukur pengembangan karakter manusia menuju lebih baik, selain itu tujuan pendidikan karakter adalah menjadikan manusia yang unggul dan memiliki kualitas.

Nilai-nilai pendidikan karakter yang terinternalisasi dalam diri peserta didik diharapkan mampu menjadikan manusia yang memiliki karakter baik. Pendidikan karakter bukan hanya sekedar materi pelajaran yang harus dihafal akan tetapi lebih jauh dari itu pendidikan karakter harus mampu memberikan pemahaman nilai karakter yang dapat dikembangkan melalui integrasi dengan materi pelajaran dan desain kegiatan khusus pendidikan karakter sehingga peseta didik tidak hanya sekedar mengetahui pendidikan karakter secara teori tetapi mampu mengaplikasikannya dalam kehidupan.

Implementasi pendidikan karakter dalam kondisi pandemi Covid-19 tentu akan berbeda dengan pelaksanaan pendidikan karakter dalam kondisi normal, dimana saat proses pendidikan dilakukan di sekolah, pendidikan karakter melalui berbagai kegiatan penanaman nilai, sikap dan perilaku dilakukan dengan pengawasan langsung oleh guru sehingga tingkat keberhasilan pendidikan karakter dapat terukur secara intensif. Berbeda dengan kondisi saat ini dimana seluruh proses pendidikan dilakukan secara daring, tidak sedikit proses pembelajaran hanya memfokuskan pada kemampuan kognitif siswa melalui transfer pengetahuan saja tanpa memperhatikan aspek afektif siswa yang mendorong pada pembentukan karakter, hal tersebut tentu bertentangan dengan konsep perubahan kurikulum KTSP tahun 2006 menjadi kurikulum 2013, dimana dalam kurikulum KTSP standar kelulusan (SKL) diukur dengan proses penilaian yang lebih dominan pada aspek pengetahuan sedangkan kurikulum 2013 mengalami pengembangan yaitu standar lulusan ditentukan melalui penilaian autentik yaitu mengukur semua kompetensi sikap, ketrampilan, dan pengetahuan berdasarkan proses dan hasil.

Oleh karena itu inovasi pendidikan karakter yang dilaksanakan di lembaga pendidikan pada masa pandemi Covid-19 ini harus terus mendapatkan perhatian, diperlukan rancangan model pendidikan karakter yang sesuai dengan kondisi pandemi Covid-19 yang pada intinya esensi pendidikan karakter harus tetap terlaksana dengan baik dalam setiap kondisi dan keadaan.

Sekolah sebagai salah satu lembaga pendidikan merupakan tempat yang ideal dalam menyelenggarakan program pendidikan karakter. Program pendidikan karakter tersebut dapat diintegrasikan ke dalam materi pelajaran juga dapat dilakukan dengan berbagai kegiatan yang mengarahkan pada pembentukan karakter peserta didik. Dengan demikian maka output pendidikan yaitu peserta didik yang berkualitas dan berkarakter tentu akan dapat tercapai.

Berdasarkan pemaparan tersebut, maka permasalahan dalam penelitian ini adalah bagaimana potret inovasi pendidikan karakter pada masa pandemi Covid-19 di SDIT Nurul Fikri?. Sehingga tujuan penelitian ini mendapatkan gambaran tentang manajemen pendidikan karakter selama pandemi Covid-19 yang dilaksanakan di sekolah. Sehingga baik sekolah, guru, maupun peserta didik mampu memahami secara komprehensif mengenai pendidikan karakter selama pandemi Covid-19 yang dilaksanakan di Sekolahnya. Adapun manfaat dari penelitian ini bisa memberikan informasi menyeluruh bagi pihak sekolah, guru dan peserta didik tentang implementasi pendidikan karakter yang pada akhirnya mampu mewujudkan tujuan pendidikan nasional yaitu mencetak generasi bangsa yang berkualitas dan berkarakter.

Terminologi manajemen sudah dikenalkan oleh George R. Terry sejak 1997, dalam bukunya yang berjudul Principles of Management. George R. Terry mengemukakan bahwa manajemen merupakan suatu proses yang berbeda terdiri dari perencanaan, pengorganisasian pelaksanaan, dan pengawasan 
yang dilakukan untuk mencapai tujuan yang ditentukan dengan menggunakan manusia dan sumber daya lainnya (Terry, 1971:10).

Berdasarkan konsep manajemen dan pengertian pendidikan yang telah dipaparkan maka manajemen pendidikan dapat diartikan sebagai proses pengelolaan pendidikan yang meliputi kegiatan perencanaan, pengorganisasian, pelaksanaan dan evaluasi kegiatan yang berkaitan dengan program pendidikan dengan memperhatikan berbagai faktor agar tujuan program pendidikan tersebut dapat tercapai secara optimal.

Sementara definisi inovasi dikemukakan oleh M. Rogers Everett (Rogers, 2010) dijelaskan bahwa inovasi adalah penemuan yang dianggap baru baik bagi individu maupun kelompok dan memiliki dampak yang baik. Pendapat lain menurut Udin Syaefudin Sa'ud mendefinisikan inovasi berarti penemuan, kata penemuan juga sering digunakan untuk menerjemahkan kata dari bahasa inggris "discovery" yang berarti penemuan yang sudah ada namun belum diketahui banyak orang, "invention" yaitu penemuan yang benar-benar baru dan innovation yang dapat diartikan sebagai ide atau gagasan, barang, kejadian, atau metode yang dirasakan dan diamati sebagai sesuatu yang baru bagi individu ataupun kelompok. Inovasi tersebut dapat berupa discovery maupun invention. Pada dasarnya inovasi bertujuan untuk mencapai tujuan tertentu untuk memberikan solusi terhadap permasalahan tertentu (Sa'ud, 2011:2).

Definisi dari karakter secara terminologi dikemukakan oleh Thomas Lickona. Thomas Lickona menyatakan bahwa karakter mulia meliputi pengetahuan tentang kebaikan, lalu menimbulkan komitmen (niat) terhadap kebaikan, dan akhirnya benar-benar melakukan kebaikan. Dalam arti lain karakter mengacu kepada serangkaian pengetahuan, sikap, motivasi, perilaku dan keterampilan. Lebih lanjut Thomas Lickona juga mengemukakan bahwa karakter berkaitan dengan konsep moral, sikap moral, dan perilaku moral (Lickona, 2012:51).

Menurut Kementerian Pendidikan Nasional (Nasional, 2010) karakter merupakan watak, tabiat, akhlak, atau kepribadian seseorang yang terbentuk dari berbagai internalisasi kebijakan yang diyakini dan digunakan sebagai landasan untuk berpikir, bertindak, dan bersikap. Karakter merupakan aspek yang sangat penting dalam pembangunan Nasional. Keterpurukan sosial suatu negara terjadi sebagai akibat rendahnya karakter masyarakat suatu negara tersebut.

Suatu program pendidikan (sekolah dan luar sekolah) yang mengorganisasikan dan menyederhanakan sumber-sumber moral dan disajikan dengan memperhatikan pertimbangan psikologis untuk pertimbangan pendidikan adalah definisi pendidikan karakter bila dilihat dari tujuan pendidikan nasional. Mengajarkan nilai-nilai tradisional tertentu, nilai-nilai yang diterima secara luas sebagai landasan perilaku yang baik dan bertanggung jawab merupakan tujuan dari pendidikan karakter.

Pendidikan karakter pada dasarnya bertujuan untuk membentuk manusia secara utuh (holistik) yang memiliki karakter, yaitu mampu mengembangkan aspek fisik, sosial, emosi, kreativitas, spiritual dan intelektual siswa dalam satuan pendidikan secara optimal. Selain itu melalui proses pendidikan karakter diharapkan manusia mampu membentuk dirinya secara utuh (insan kamil).

Thomas Lickona menyebutkan tujuh unsur-unsur karakter esensial dan utama yang harus ditanamkan kepada peserta didik yang meliputi, Ketulusan hati atau kejujuran, belas kasih, keberanian, kasih sayang, kontrol diri, kerjasama, dan kerja keras (Lickona, 2012: 5).

Nilai-nilai karakter telah dirumuskan oleh Kementerian Pendidikan Nasional yang dimual dalam naskah akademik Pengembangan Pendidikan Budaya dan Karakter Bangsa, nilai karakter ini akan dikembangkan atau ditanamkan kepada anak-anak dan generasi muda bangsa Indonesia. Implementasi 18 nilai tersebut adalah: religius, jujur, toleransi, disiplin, kerja keras, kreatif, mandiri, demokratis, rasa ingin tahu, semangat kebangsaan, cinta tanah air, menghargai prestasi, bersahabat/ komunikatif, cinta damai, gemar membaca, peduli lingkungan, peduli sosial, dan tanggung jawab.

Adapun dalam desain induk Pendidikan Karakter, Kementerian Pendidikan dan Kebudayaan RI juga telah menjelaskan konfigurasi karakter dalam konteks proses psikososial dan sosial-kultural dalam empat kelompok besar, yaitu, Olah Hati (spiritual and emotional development), Olah Pikir (intellectual development), Olah Raga dan Kinestetik (physical and kinesthetic development) serta Olah Rasa dan Karsa (affective and creativity development). 
Keempat kelompok konfigurasi karakter tersebut memiliki unsur- unsur karakter inti yang dapat dijelaskan dalam tabel 2 sebagai berikut:

Tabel 1. Konfigurasi Karakter Inti (KI)

\begin{tabular}{|c|c|c|}
\hline No & Kelompok & $\mathrm{KI}$ \\
\hline 1 & Olah Hati & $\begin{array}{l}\text { - Religius } \\
\text { - Jujur } \\
\text { - Tanggung Jawab } \\
\text { - Peduli Sosial } \\
\text { - Peduli Lingkungan }\end{array}$ \\
\hline 2 & Olah Fikir & $\begin{array}{l}\text { - Cerdas } \\
\text { - Kreatif } \\
\text { - Gemar Membaca } \\
\text { - Rasa Ingin Tahu }\end{array}$ \\
\hline 3 & Olah Raga & $\begin{array}{l}\text { - Sehat } \\
\text { - Bersih }\end{array}$ \\
\hline 4 & Olah Rasa dan Karsa & $\begin{array}{l}\text { - Peduli } \\
\text { - Kerjasama }\end{array}$ \\
\hline
\end{tabular}

Optimalisasi pendidikan karakter di Sekolah tidak terlepas dari model atau pendekatan yang dilakukan dalam proses penanaman dan pembiasaan karakter yang baik. Menurut Zubaedi setidaknya terdapat tiga pendekatan yang dilakukan dalam proses pendidikan karakter di Sekolah, tiga hal tersebut diantaranya: Integrasi pendidikan karakter dengan semua materi pembelajaran, muatan lokal dan pendidikan pengembangan diri melalui ekstrakulikuler. Kegiatan pembiasaan melalui budaya sekolah yang mengarah pada pembentukan karakter siswa; Kerjasama antara semua komponen yang berperan dalam pembentukan karakter siswa komponen tersebut meliputi sekolah, orang tua siswa dan masyarakat sekitar (Zubaedi, 2015:14).

Pendekatan tersebut bertujuan untuk meningkatkan kualitas karakter siswa sehingga siswa memiliki perilaku dan kebiasaan yang mencerminkan nilai-nilai karakter baik di lingkungan sekolah, lingkungan keluarga maupun lingkungan masyarakat.

Penyelenggaraan PPK berdasarkan Peraturan Presiden (Perpres) No 87 Tahun 2017 pada satuan pendidikan jalur pendidikan formal dilakukan secara terintegrasi dalam kegiatan Intrakurikuler, Kokurikuler dan Ekstrakurikuler. Penyelenggaraan PPK dilaksanakan di dalam dan/atau di luar lingkungan satuan pendidikan formal, dengan prinsip manajemen berbasis sekolah/madrasah dan merupakan tanggung jawab kepala satuan pendidikan formal dan guru. Pemenuhan beban kerja guru dan kepala satuan pendidikan formal merupakan tanggung jawab yang harus dilaksanakan.

Penguatan nilai-nilai karakter melalui kegiatan penguatan materi pembelajaran, dan metode pembelajaran sesuai dengan muatan kurikulum merupakan penyelenggaraan PPK dalam kegiatan intrakurikuler. Sedangkan penguatan nilai-nilai karakter yang dilaksanakan untuk pendalaman dan/ atau pengayaan kegiatan intrakurikuler sesuai muatan kurikulum merupakan penyelenggaraan PPK dalam kegiatan kokurikuler. Penyelenggaraan PPK dalam kegiatan ekstrakurikuler adalah penguatan nilai-nilai karakter dalam rangka perluasan potensi, bakat, minat, kemampuan, kepribadian, kerjasama, dan kemandirian peserta didik secara optimal.

Pelaksanaan PPK dalam buku konsep dan panduan penguatan pendidikan karakter (PPK) tingkat sekolah dasar dan menengah (Kemdikbud, 2017) disampaikan bahwa pelaksanaan PPK disesuaikan dengan kurikulum pada satuan pendidikan masing-masing dan dapat dilakukan dengan tiga cara yaitu melalui pembelajaran, ekstrakurikuler, dan pembiasaan melalui budaya sekolah, implementasi PPK tersebut dapat digambarkan dalam gambar 1 sebagai berikut:

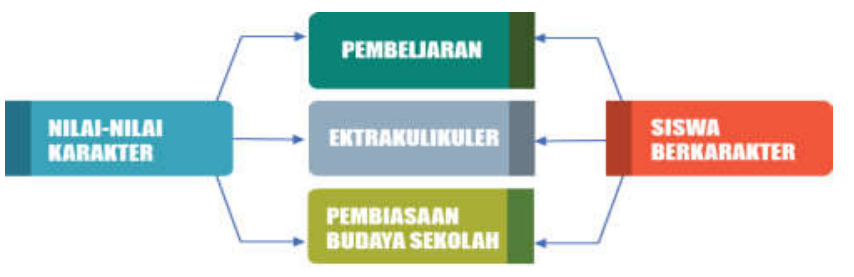

Gambar 1. Implementasi PPK di Sekolah 
Integrasi pendidikan karakter ke dalam seluruh mata pelajaran baik melalui kegiatan intrakurikuler maupun kokurikuler. Sebagai kegiatan intrakurikuler dan kokurikuler setiap guru menyusun dokumen perencanaan pembelajaran berupa silabus dan RPP dengan mengintegrasikan materi pelajaran dengan karakter yang akan dikembangkan yang sesuai dengan materi pelajaran. Implementasi PPK melalui proses pembelajaran dapat digambarkan dalam gambar 2 sebagai berikut:

Gambar 2. Implementasi PPK melalui Pembelajaran

Mengimplementasikan PPK melalui kegiatan ekstrakulikuler yang ditetapkan oleh satuan pendidikan, pada kegiatan ekstrakurikuler satuan pendidikan melakukan penguatan nilai-nilai karakter degan berbagai kegiatan, kegiatan ekstrakulikuler dapat dilakukan denga kolaborasi dan kerjasama dengan berbagai pihak sesuai kebutuhan satuan pendidikan. Implementasi PPK melalui kegiatan ekstrakulikuler dapat digambarkan dalam gambar 3 sebagai berikut:

Gambar 3. Implementasi PPK melalui Ekstrakurikuler

Melalui budaya sekolah, kegiatan pembiasaan dibentuk dalam proses kegiatan rutin, spontan, pengkondisian, dan keteladanan warga sekolah. Untuk memperkuat pembentukan karakter sesuai dengan situasi, kondisi, ketersediaan sarana prasarana di setiap satuan pendidikan maka kegiatan pembiasaan tersebut dilakukan di luar jam pembelajaran. Implementasi PPK melalui pembiasaan dan budaya sekolah dapat digambarkan dalam gambar 4 sebagai berikut:

Gambar 4. Implementasi PPK melalui Pembiasaan dan Budaya Sekolah

\section{METODE PENELITIAN}

Penelitian akan dilakukan di Sekolah Dasar Islam Terpadu Nurul Fikri yang beralamat di Jl. Tugu Raya No.61, Tugu, Kec. Cimanggis, Kota Depok, Jawa Barat (116451). Penelitian dilakukan di SDIT Nurul Fikri karena SDIT Nurul Fikri memiliki sistem pendidikan berbasis integrasi pendidikan karakter, SDIT Nurul Fikri berkomitmen untuk terus berinovasi menyajikan pendidikan karakter meskipun pembelajaran dilakukan secara daring, mengalami secara langsung proses pendidikan karakter yang dilaksanakan selama pandemi Covid-19. Penelitian dilakukan secara bertahap yaitu selama 7 bulan dimulai dari bulan September 2020 sampai dengan bulan Maret 2021.

Penelitian ini merupakan jenis penelitian mix methods yaitu pendekatan penelitian yang menggabungkan dua metode penelitian yaitu metode penelitian kualitatif dan kuantitatif. Mix methods disebut juga sebagai penelitian campuran sebagaimana yang di kemukakan Menurut Creswell mendefinisikan penelitian campuran adalah penelitian yang mengkombinasikan penelitian kualitatif dengan penelitian kuantitatif (Creswell, 2010:5). Melengkapi pendapat tersebut Sugiyono mengemukakan bahwa mix methods adalah penelitian kombinasi kualitatif dan kuantitatif yang dilakukan pada suatu kegiatan sehingga didapatkan hasil penelitian yang lebih komprehensif, valid, reliabel dan objektif (P. Sugiyono, 2011:18) 
Pendekatan mix methods dalam penelitian ini digunakan untuk menjawab rumusan masalah yang telah dikemukakan sebelumnya. Pendekatan kualitatif akan digunakan untuk menjawab seluruh rumusan masalah sedangkan pendekatan kuantitatif akan digunakan sebagai data pelengkap untuk menjawab rumusan masalah khususnya pada rumusan masalah implikasi pendidikan karakter terhadap perkembangan karakter siswa.

Metode dalam mengumpulkan data yang digunakan dalam penelitian ini adalah observasi, wawancara, dan dokumentasi dan untuk melengkapi data tersebut akan dilakukan penyebaran angket dalam bentuk kuesioner.

Adapun analisis data yang pertama dilakukan adalah analisis data kualitatif sebagaimana yang dikemukakan oleh Sugiyono bahwa terdapat tiga tahap proses analisis data dalam penelitian kualitatif yaitu Reduction Data, Display Data dan Verifikasi Data (P. D. Sugiyono, 2010).

Kemudian karena penelitian ini juga menggunakan pendekatan kualitatif maka proses analisis data membutuhkan analisis yang menggunakan angka dengan skala Likert. Maka berkenaan dengan analisis data skala Likert, Sugiyono mengungkapkan bahwa dengan tujuan untuk mengetahui persentase dan frekuensi masing-masing alternatif jawaban serta untuk memudahkan dalam membaca data maka data yang diperoleh disajikan dengan bentuk tabel (P. D. Sugiyono, 2010). Hasil angket dianalisis dengan cara mencari persentase masing-masing pernyataan untuk setiap pilihan jawaban, yaitu dengan menggunakan rumus sebagai berikut:

\section{$P=f / n \times 100 \%$}

Keterangan:

$\mathrm{P} \quad=$ Angka persentase

$f \quad=$ Frekuensi Jawaban,

$n \quad$ = Banyaknya responden

Mengenai analisis data angket, Sugiyono (P. D. Sugiyono, 2010) mengungkapkan bahwa data yang telah dipresentasikan kemudian ditentukan persentase angket keseluruhan dengan mengelompokkan data berdasarkan jenis pernyataan, yaitu pernyataan positif dan pernyataan negatif, selanjutnya hasil ditafsirkan dengan menggunakan kategori persentase yaitu pada tabel 2 berikut:

Tabel 2. Interpretasi Persentase Penilaian

\begin{tabular}{ll}
\hline$P(\%)$ & Kriteria \\
\hline$P=0$ & Tak seorangpun \\
$1<$ P M 25 & Sebagian kecil \\
$25<$ p M 50 & Hampir setengahnya \\
$P=50$ & Setengahnya \\
$50<P<75$ & Sebagian besar \\
$75<P$ M 100 & Hampir seluruhnya \\
$P=100$ & Seluruhnya \\
\hline
\end{tabular}

Proses atau tahapan berikutnya dalam analisis instrumen data dengan pendekatan kuantitatif ini dapat dilakukan dengan analisis data instrumen expert judgment. Gonia mengemukakan bahwa dalam skala pengukuran rating scale dapat digunakan untuk menentukan tingkat validitas instrumen penelitian. Agar dapat digunakan sesuai tujuan penelitian, maka data kualitatif ditransformasikan terlebih dahulu berdasarkan bobot skor yang telah ditetapkan menjadi data kuantitatif, yakni satu, dua, tiga, dan empat dan seterusnya (Gonia, 2009: 50)

Data ini merupakan data kuantitatif yang selanjutnya akan dianalisis dengan statistik deskriptif. Lebih lanjut Gonia mengemukakan bahwa tingkat validitas dengan menggunakan pengukuran rating scale dapat dilakukan dengan menggunakan rumus sebagai berikut:

\section{$P=(f / n \times t) \times 100 \%$}

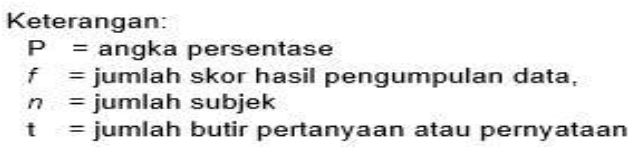


Selanjutnya menurut Gonia (Gonia, 2009: 53) tingkat validasi implikasi manajemen inovasi pendidikan karakter dalam penelitian ini digolongkan dalam empat kategori dengan menggunakan skala sebagai berikut:

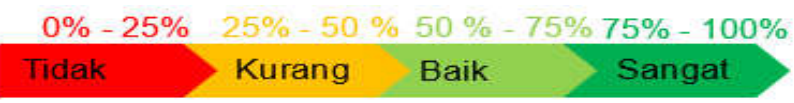

Berdasarkan katagori tersebut data hasil penelitian dapat digunakan sejauh mana efektivitas manajemen inovasi pendidikan karakter selama pandemi Covid-19 memiliki dampak atau implikasi terhadap pembentukan dan pengembangan karakter siswa di SDIT Nurul Fikri.

\section{PEMBAHASAN}

Nilai karakter yang dikembangkan di SDIT Nurul Fikri adalah karakter SMART yaitu sholeh, muslih, cerdas, mandiri dan terampil yang merupakan salah satu program unggulan yang dilaksanakan oleh SDIT Nurul Fikri. Nilai-nilai karakter SMART. Indikator pengembangan karakter SMART SDIT Nurul Fikri dapat dilihat pada tabel 3 berikut:

Tabel 3. Karakter SMART SDIT Nurul Fikri

\begin{tabular}{|c|c|c|c|c|c|}
\hline No & Sholeh & Muslih & Cerdas & Mandiri & Terampil \\
\hline 1 & Taat beribadah & $\begin{array}{l}\text { Berjiwa } \\
\text { pemimpin }\end{array}$ & Keingintahuan & Kreatif & Tangkas (aktivitas motorik) \\
\hline 2 & Berakidah ahlusunnah & Berjiwa pelopor & Berpikir mendalam & Berjiwa enterpreuner & Cekatan (sikap) \\
\hline 3 & & $\begin{array}{l}\text { Bertanggung } \\
\text { jawab }\end{array}$ & $\begin{array}{l}\text { Terbuka terhadap } \\
\text { gagasan baru }\end{array}$ & $\begin{array}{l}\text { Berani mengambil } \\
\text { keputusan }\end{array}$ & Terampil berbahasa \\
\hline 4 & & Peduli & Penyelesaian masalah & & Menguasai teknologi informasi \\
\hline 5 & & Cinta tanah air & Berpengetahuan & & Menguasai olahraga \\
\hline 6 & & Komunikasi & Berpikir ilmiah & & Menguasai kesenian \\
\hline 7 & & Kerjasama & & & \\
\hline
\end{tabular}

Berdasarkan tabel karakter SMART tersebut dapat disimpulkan bahwa nilai-nilai pendidikan karakter yang dikembangkan oleh SDIT Nurul Fikri telah sesuai dengan teori yang dikemukakan oleh Thomas Lickona terkait karakter esensial dan utama yang harus ditanamkan kepada peserta didik yaitu ketulusan hati atau kejujuran (honesty, belas kasih (compassion), keberanian (courage), kasih sayang (kindness), kontrol diri (self-control), kerjasama (cooperation), kerja keras (diligence or hard work). Selain itu karakter SMART juga merupakan penerjemahan dari 18 nilai karakter yang telah dirumuskan oleh Kementerian Pendidikan dan Kebudayaan RI serta telah sesuai dengan konfigurasi karakter dalam konteks proses psikososial dan sosial-kultural dalam empat kelompok besar, yaitu olah hati (spiritual and emotional development), olah pikir (intellectual development), olah raga dan kinestetik (physical and kinesthetic development), dan olah rasa dan karsa (affective and creativity development).

Manajemen inovasi pendidikan karakter di SDIT Nurul Fikri menggunakan model atau pendekatan POAC yaitu planning (perencanaan) pengembangan karakter pada masa pandemi Covid-19 di SDIT Nurul Fikri adalah mengarah kepada penetapan tujuan yang hendak dicapai dan perumusan program pendidikan karakter akan dilaksanakan pada masa pandemi covid-19 baik yang terintegrasi secara langsung dalam pembelajaran maupun kegiatan ekstrakurikuler dan pembiasaan.

Proses perencanaan pendidikan karakter melalui kegiatan pembelajaran, ekstrakurikuler, dan pembiasaan dapat dilihat pada tabel 4 berikut:

Tabel 4. Proses Perencanaan (Planing) Pendidikan Karakter

\begin{tabular}{cc}
\hline \multicolumn{2}{c}{ Proses Perencanaan Pendidikan Karakter } \\
\hline \multicolumn{1}{c}{ Ekstrakurikuler dan Pembiasaan } & Pembelajaran \\
[Wakasis] & {$[$ Wakakur] } \\
Rekayasa kegiatan pendidikan & Redesain Format Silabus dan RPP \\
karakter pada masa pandemi covid-19 & [Integrasi Pendidikan Karakter] \\
\hline
\end{tabular}

Proses organizing (pengorganisasian) yang meliputi penetapan jadwal pelajaran dan jadwal pelaksanaan program pendidikan karakter serta penetapan penanggung jawab dari setiap program. 
Proses pengorganisasian pendidikan karakter melalui kegiatan pembelajaran, ekstrakurikuler, dan pembiasaan dapat dilihat pada tabel 5 berikut:

Tabel 5. Proses Pengorganisasian (Organizing) Pendidikan Karakter

\begin{tabular}{ccc}
\hline \multicolumn{2}{c}{ Proses Pengorganisasian Pendidikan Karakter } \\
\hline \multicolumn{2}{c}{ Ekstrakurikuler dan Pembiasaan } & Pembelajaran \\
[Wakasis] & [Wakakur $]$ \\
& - & Pembuatan Jadwal Pelajaran \\
- & Pembuatan Jadwal Kegiatan & Penetapan Materi Prioritas \\
\hline
\end{tabular}

Proses actuating yaitu pelaksanaan pendidikan karakter melalui pembelajaran, ekstrakurikuler, dan pembiasaan budaya sekolah di bawah koordinasi dan pengarahan kepala sekolah kepada setiap guru dan PJ kegiatan,

Proses pelaksanaan (actuating) pendidikan karakter pada masa pandemi covid-19 di SDIT Nurul Fikri yang dilaksanakan dibawah tanggung jawab wakasis dan wakakur dapat diuraikan dalam tabel 6 berikut:

Tabel 6. Proses Pelaksanaan (Actuating) Pendidikan Karakter

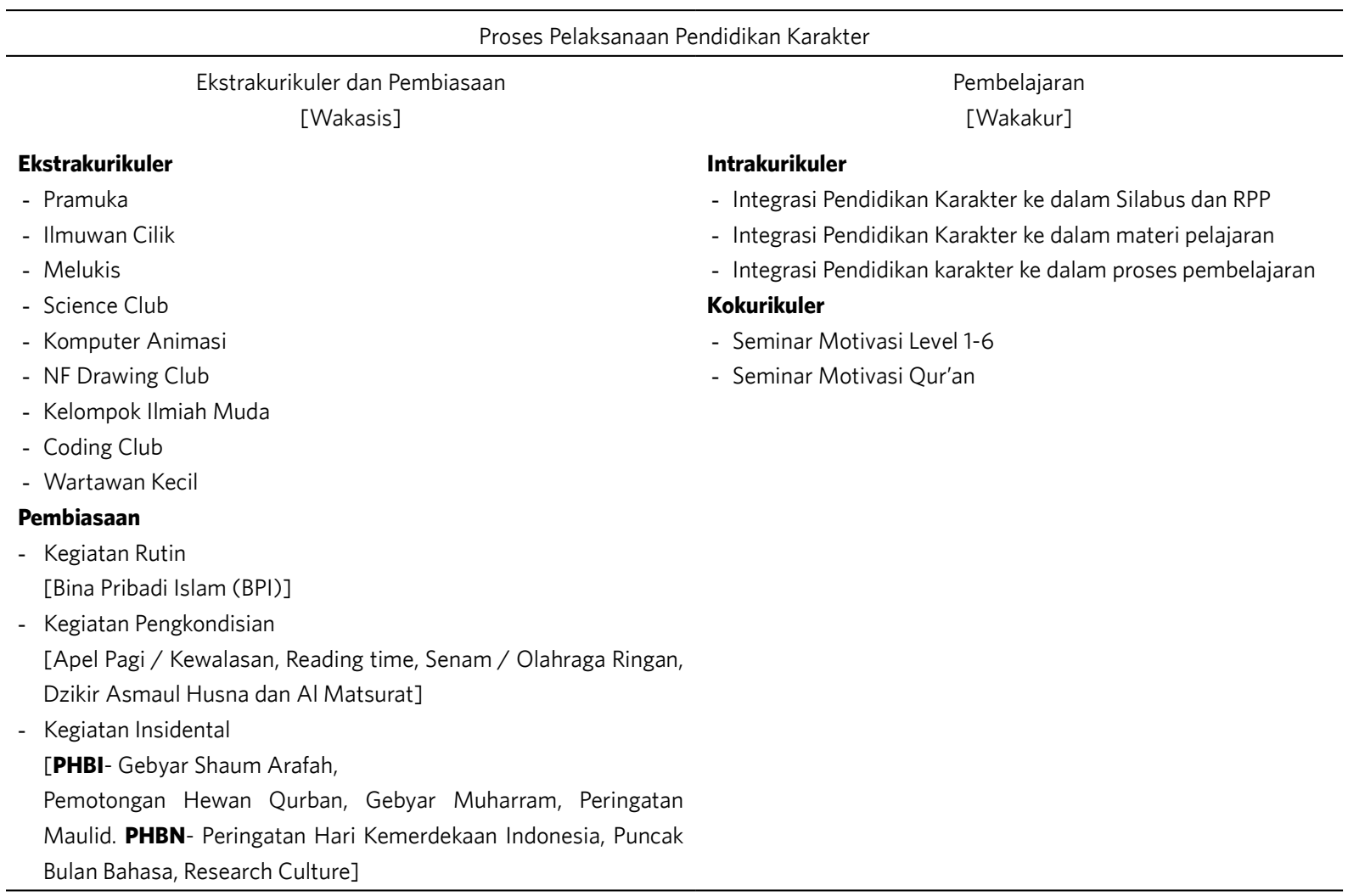

Implementasi fungsi manajemen yang terakhir adalah controlling (pengawasan), proses pengawasan pendidikan karakter yang terintegrasi dengan materi pelajaran dan proses pembelajaran dilakukan dengan supervisi yang dilakukan baik oleh kepala sekolah maupun guru yang telah tersertifikasi sedangkan proses pengawasan pendidikan karakter melalui berbagai kegiatan yang berada di bawah tanggung jawab wakasis dilakukan dengan form mutaba'ah dan evaluasi kegiatan yang diisi oleh siswa dan orang tua yang akan digunakan sebagai tolak ukur keberhasilan program pendidikan karakter yang dilaksanakan terhadap perkembangan karakter siswa. Proses pengawasan (controlling) pendidikan karakter pada masa pandemi covid-19 di SDIT Nurul Fikri yang dilaksanakan dibawah tanggung jawab wakasis dan wakakur dapat diuraikan dalam tabel 7 berikut: 
Tabel 7. Proses Pengawasan (Controlling) Pendidikan Karakter

\begin{tabular}{cc}
\hline \multicolumn{2}{c}{ Proses Pengawasan Pendidikan Karakter } \\
\hline Ekstrakurikuler dan Pembiasaan & Pembelajaran \\
[Wakasis] & [Wakakur] \\
- Laporan PJ Kegiatan & - Supervisi \\
- Rapat Koordinasi Pekanan & - Rapat Pekanan dan Rapat \\
- Pengawasan Langsung & Koordinasi \\
- Form Mutaba'ah & \\
\hline
\end{tabular}

Berdasarkan hasil temuan pada proses perencanaan, dapat disimpulkan bahwa proses perencanaan yang dilakukan oleh SDIT Nurul Fikri telah dilakukan dengan baik hal tersebut karena SDIT Nurul Fikri meyakini bahwa proses perencanaan program sangat penting untuk dilakukan. Perencanaan pengembangan karakter pada masa pandemi Covid-19 di SDIT Nurul Fikri adalah mengarah kepada penetapan tujuan yang hendak dicapai dan menentukan program yang sesuai untuk mencapai tujuan yang telah ditetapkan hal tersebut sesuai dengan yang dikemukakan oleh George R. Terry bahwa konsep perencanaan mengarah kepada rancangan berbagai aktivitas untuk mencapai tujuan yang telah ditetapkan. Konsep perencanaan yang dibuat juga telah sesuai dengan yang dikemukakan oleh Nanang Fatah (Fattah, 2009: 24) dalam setiap perencanaan selalu terdapat tiga kegiatan yang meskipun tidak dapat dipisahkan namun dapat dibedakan antara satu dengan yang lainnya dalam proses perencanaan. Ketiga kegiatan tersebut terdiri dari perumusan tujuan yang ingin dicapai, pemilihan program untuk mencapai tujuan itu dan identifikasi dan pengarahan sumber yang jumlahnya selalu terbatas.

Proses manajemen selanjutnya yang dilakukan oleh SDIT Nurul Fikri adalah proses pengorganisasian atau mengorganisasikan, proses organizing menurut George R. Terry berfungsi sebagai penentuan, pengelompokan dan pengaturan berbagai kegiatan yang diperlukan untuk pencapaian tujuan, penugasan individu-individu untuk kegiatan, penyediaan faktor fisik lingkungan yang sesuai dan menunjukkan otoritas relatif yang didelegasikan untuk setiap kegiatan yang telah direncanakan. Pengorganisasian menurut Nanang Fatah juga berfungsi sebagai pengarah pencapaian tujuan bersama dengan menekankan adanya kerjasama yang baik antara anggota kelompok.

Temuan terkait proses organizing (pengorganisasian) dapat disimpulkan bahwa berdasarkan data dan fakta lapangan yang dilakukan pada proses organizing di SDIT Nurul Fikri telah sesuai dengan konsep teori yang dikemukakan oleh George R. Terry yaitu proses pengelompokan individu dan penugasan individu untuk berbagai kegiatan dan menentukan otoritas atau penanggung jawab setiap kegiatan, proses pengorganisasian yang dilakukan oleh SDIT Nurul Fikri juga telah dilaksanakan dengan baik karena telah memenuhi karakteristik tahap pengorganisasian sebagaimana yang dikemukakan oleh Nanang Fatah (Fattah, 2009: 36). Sistem pengorganisasian harus senantiasa mempunyai karakteristik, antara lain: (1) Ada komunikasi antara orang yang bekerjasama; (2) Individu dalam organisasi tersebut mempunyai kemampuan untuk bekerjasama; (3) Kerjasama itu ditunjukkan untuk mencapai tujuan.

Proses pelaksanaan program (Actuating) pendidikan karakter di SDIT Nurul Fikri berdasarkan temuan adalah dilakukan melalui pembelajaran, ekstrakurikuler dan pembiasaan. Upaya yang dilakukan oleh kepala sekolah agar program kegiatan pendidikan karakter terlaksana dengan baik adalah dengan memberikan arahan baik secara khusus maupun secara umum dalam rapat pekanan, hal tersebut berdasarkan analisa sesuai dengan yang dikemukakan oleh George R. Terry yang mengemukakan bahwa pelaksanaan (actuating) adalah upaya mendorong anggota kelompok agar bisa bekerja dengan maksimal untuk mencapai tujuan yang sesuai dengan perencanaan dan upaya pengorganisasian yang telah ditetapkan.

Proses manajemen terakhir yang dilakukan oleh SDIT Nurul Fikri adalah proses controlling. Upaya yang dilakukan oleh SDIT Nurul Fikri dalam proses pengawasan adalah dengan menetapkan standar kinerja dan tindakan pengawasan agar tujuan dari setiap program dapat tercapai sesuai dengan yang telah direncanakan, hal tersebut adalah sesuai dengan yang dikemukakan oleh George R. Terry. Proses Pengendalian atau pengawasan dapat diartikan sebagai proses menentukan standar yang akan dicapai yang terdiri dari kinerja, evaluasi kinerja, dan tindakan korektif agar kinerja berjalan 
sesuai dengan standar yang telah ditetapkan dalam proses perencanaan. Pengawasan untuk integrasi pendidikan karakter dilakukan melalui supervisi sedangkan untuk kegiatan kesiswaan dilakukan melalui form mutaba'ah mingguan. Proses pengawasan yang dilakukan oleh SDIT Nurul Fikri adalah untuk memastikan bahwa program kegiatan pendidikan karakter terlaksana sesuai dengan yang telah direncanakan hal tersebut sesuai dengan yang dikemukakan oleh Engkoswara bahwa pengawasan adalah salah satu fungsi dalam manajemen untuk menjamin agar pelaksanaan kerja berjalan sesuai dengan standar yang telah ditetapkan dalam perencanaan. Pengawasan/pengendalian adalah proses untuk memastikan bahwa aktivitas sebenarnya sesuai dengan aktivitas yang direncanakan (Engkoswara \& Komariah, 2010: 96).

Selain itu SDIT Nurul Fikri berkomitmen untuk mengantisipasi setiap perkembangan dengan terus menerus mengupayakan inovasi suatu program yang sesuai dengan perkembangan zaman, situasi, kondisi dan kebutuhan perserta didik, sehingga program pendidikan karakter tetap terlaksana dengan optimal meski di tengah kondisi pandemi Covid-19. Inovasi pendidikan karakter yang dilakukan di SDIT Nurul Fikri berdasarkan hasil temuan adalah dengan memanfaatkan teknologi yang dapat menunjang proses pendidikan karakter agar tetap terlaksana dengan optimal meski dalam kondisi pandemi covid-19. Lebih lanjut inovasi pendidikan karakter dan proses manajemen yang dilakukan SDIT Nurul Fikri digambarkan dalam gambar berikut:

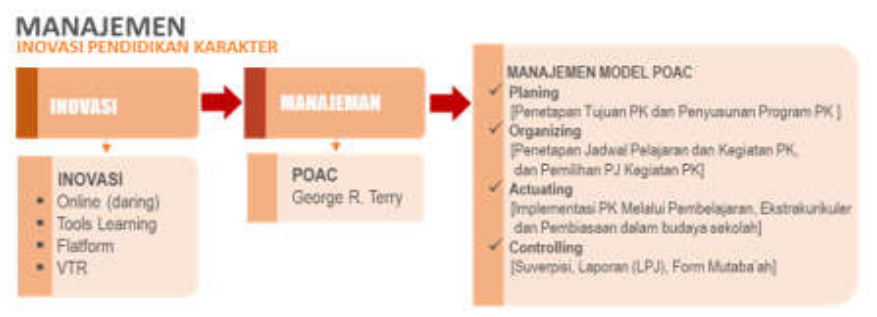

Gambar 5. Kerangka Manajemen Inovasi Pendidikan Karakter

Faktor pendukung implementasi inovasi pendidikan karakter di SDIT Nurul Fikri diantaranya adalah kesiapan lembaga pendidikan untuk merancang program pendidikan karakter yang sesuai dengan tujuan karakter SMART dan sesuai dengan kebutuhan siswa pada masa pandemi Covid-19, sumber daya manusia baik pendidik maupun tenaga kependidikan yang berkualitas dan menunjukan sikap serta perilaku yang baik yang dapat dicontoh oleh siswa, sarana pendukung program pendidikan karakter yang memadai, dan model atau pola komunikasi dan kerjasama sekolah melalui guru dengan orang tua siswa yang sistematis dan terjalin dengan baik.

Berdasarkan temuan hasil penelitian tersebut, dapat disimpulkan bahwa faktor pendukung implementasi pendidikan karakter di SDIT Nurul Fikri dalam kondisi pandemi melalui tabel 8 berikut:

Tabel 8. Faktor Pendukung Implementasi Pendidikan Karakter

\begin{tabular}{|c|c|c|}
\hline No & Faktor Pendukung & Keterangan \\
\hline 1 & Kesiapan Lembaga & $\begin{array}{l}\text { - Desain Program Pendidikan Karakter } \\
\text { - } \quad \text { Format silabus dan RPP yang mengintegrasikan pendidikan karakter }\end{array}$ \\
\hline 2 & SDM & $\begin{array}{ll}\text { - } & \text { Program Pelatihan dan pendampingan guru } \\
\text { - } & \text { Kerjasama Guru } \\
\text { - } & \text { Evaluasi berkelanjutan } \\
\text { - } & \text { Sikap dan Perilaku Guru yang Baik }\end{array}$ \\
\hline 3 & Sarana Pendukung & $\begin{array}{ll}\text { - } & \text { Akun zoom premium } \\
\text { - } & \text { Standarisasi GCR } \\
\text { - } & \text { Tools learning } \\
\text { - } & \text { NFRS (Nurul Fikri Reading System) } \\
\text { - } & \text { SIMSIT } \\
\text { - } & \text { You tube SIT Nurul Fikri } \\
\text { - } & \text { Website resmi dan media sosial }\end{array}$ \\
\hline 4 & Komunikasi & $\begin{array}{ll}\text { - } & \text { Sistematis } \\
\text { - } & \text { Program SEKATA } \\
\text { - } & \text { Korlas dan Komite }\end{array}$ \\
\hline
\end{tabular}


Kendala dan solusi yang dihadapi oleh SDIT Nurul Fikri dalam melaksanakan pendidikan karakter pada masa pandemi covid-19 diantaranya adalah masih ada guru yang hanya terfokus menyampaikan materi pelajaran tidak mengintegrasikan pendidikan karakter dalam proses pembelajaran hal tersebut adalah karena materi pelajaran yang padat dengan waktu yang terbatas solusi dari kendala tersebut adalah penyederhanaan materi pelajaran (materi prioritas) serta evaluasi dalam bentuk supervisi, rendahnya kesadaran orangtua untuk memberikan pendidikan karakter di lingkungan keluarga solusi dari kendala tersebut adalah sekolah menyelenggarakan kegiatan seminar dan parenting untuk orangtua terkait peran orangtua dalam mengembangkan karakter siswa di lingkungan keluarga, kendala selanjutnya adalah sulitnya memantau perkembangan karakter siswa dalam kondisi pembelajaran dilakukan secara daring hal tersebut adalah karena siswa lebih banyak berada di rumah, solusi dari kendala tersebut adalah sekolah melalui wakasis bekerjasama dengan para wali kelas dan pembina BPI membuat form mutaba'ah harian dan mingguan yang berfungsi untuk mengetahui dan memantau perkembangan karakter siswa.

Berdasarkan temuan hasil penelitian tersebut, dapat disimpulkan bahwa kendala dan solusi dari implementasi pendidikan karakter di SDIT Nurul Fikri dalam kondisi pandemi melalui tabel 9 berikut:

Tabel 9. Kendala dan Solusi Implementasi Pendidikan Karakter

\begin{tabular}{|c|c|c|}
\hline No & Kendala & Solusi \\
\hline 1 & $\begin{array}{l}\text { Guru hanya terfokus menyampaikan } \\
\text { materi pelajaran karena Materi } \\
\text { Pelajaran yang padat }\end{array}$ & $\begin{array}{l}\text { - Penyederhanaan Materi Pelajaran (Materi } \\
\text { Prioritas) } \\
\text { - } \quad \text { Evaluasi dalam bentuk supervisi }\end{array}$ \\
\hline 2 & $\begin{array}{l}\text { Rendahnya kesadaran orangtua untuk } \\
\text { memberikan pendidikan karakter di } \\
\text { lingkungan keluarga }\end{array}$ & $\begin{array}{l}\text { - Seminar dan Parenting terkait peran } \\
\text { orangtua dalam mengembangkan karakter } \\
\text { siswa }\end{array}$ \\
\hline 3 & $\begin{array}{l}\text { Pemantauan Perkembangan Karakter } \\
\text { siswa }\end{array}$ & - Form Mutaba'ah Mingguan \\
\hline
\end{tabular}

Komitmen SDIT Nurul Fikri untuk tetap menyajikan pendidikan karakter meski dalam kondisi pandemi berdampak positif terhadap perkembangan karakter SMART siswa hal tersebut adalah berdasarkan hasil angket yang telah disebarkan kepada 96 siswa level 6, hasil angket tersebut menunjukan dari 96 siswa sebagai responden kurang lebih 40 siswa yaitu jawaban sangat sering menunjukan perkembangan karakter yang sangat baik, kurang lebih 42 siswa yaitu jawaban sering menunjukan perkembangan karakter SMART yang baik sedangkan kurang lebih 14 orang siswa yaitu jawaban jarang dan kadang-kadang menunjukan perkembangan karakter SMART siswa yang cukup baik, dan jawaban tidak pernah yaitu hanya $0.2 \%$ menunjukan hampir tidak ada siswa yang tidak mengalami perkembangan karakter SMART.

\section{KESIMPULAN DAN SARAN}

Nilai karakter yang dikembangkan di SDIT Nurul Fikri adalah karakter SMART yaitu sholeh, muslih, cerdas, mandiri dan terampil. Implementasi pendidikan karakter pada masa pandemi Covid-19 di SDIT Nurul Fikri telah menjalankan fungsi-fungsi manajemen pendidikan yaitu (POAC) yang terdiri dari planning (perencanaan), organizing (pengorganisasian), actuating (pelaksanaan) dan controlling (pengawasan). Implementasi pendidikan karakter SMART dilaksanakan dengan mengintegrasikan pendidikan karakter dengan pembelajaran, terintegrasi dengan berbagai kegiatan ekstrakurikuler serta terintegrasi dengan kegiatan pembiasaan dan budaya sekolah. Komitmen SDIT Nurul Fikri untuk tetap menyajikan pendidikan karakter meski dalam kondisi pandemi berdampak positif terhadap perkembangan karakter SMART siswa

Berdasarkan simpulan hasil penelitian dan pembahasan yang telah dipaparkan, berikut ini adalah saran yang dapat sampaikan agar pendidikan karakter di sekolah dapat dilaksanakan secara optimal sehingga tujuan pendidikan nasional yaitu selain dapat meningkatkan kemampuan pengetahuan siswa juga mampu mengembangkan karakter siswa.

Saran tersebut adalah sebagai berikut: Pertama, untuk kepala Sekolah SDIT Nurul Fikri diharapkan tetap konsisten untuk menjalankan fungsinya yaitu untuk mengarahkan dan melakukan evaluasi terhadap program pendidikan karakter yang dilaksanakan. 
Kedua, bagi guru SDIT Nurul Fikri diharapkan untuk melaksanakan proses pembelajaran yang tidak hanya terfokus kepada meningkatkan pengetahuan siswa tetapi juga proses pembelajaran yang mampu mengembangkan karakter siswa.

Ketiga, bagi pemerintah diharapkan terus berupaya untuk meningkatkan program pendidikan karakter baik dalam aspek kurikulum maupun kualitas guru melalui pelatihan terkait strategi implementasi pendidikan karakter.

Keempat, bagi Sekolah atau lembaga pendidikan diharapkan mampu merancang program pendidikan karakter dengan terus berinovasi agar program pendidikan karakter tetap bisa dilaksanakan dengan optimal dalam setiap situasi dan kondisi.

\section{PUSTAKA ACUAN}

Creswell, J. W. (2010). Research design pendekatan kualitatif, kuantitatif, dan mixed. Yogyakarta: Pustaka Pelajar.

Engkoswara, A. K., \& Komariah, A. (2010). Administrasi pendidikan. Bandung: Alfabeta.

Fattah, N. (2009). Landasan manajemen pendidikan.

Gonia, M. F. (2009). Pengembangan Multimedia Interaktif untuk Assessmen Pembelajaran Pembiasan Cahaya. Skripsi Program Studi Pendidikan IImu Komputer. FMIPA-UPI: Tidak Diterbitkan

Lickona, T. (2012). Character Matters: Persoalan Karakter,(terj. Juma Wadu Wamaungu \& Jean Antunes Rudolf Zien dan Editor Uyu Wahyuddin dan Suryani). Jakarta: Bumi Aksara.

Nasional, K. P. (2010). Pengembangan pendidikan budaya dan karakter bangsa: pedoman sekolah. Jakarta: Badan Penelitian Dan Pengembangan.

Pendidikan, K., \& Indonesia, K. R. (2017). Konsep dan Pedoman Penguatan Pendidikan Karakter Tingkat Sekolah Dasar dan Sekolah Menengah Pertama. Jakarta: Kementerian Pendidikan Dan Kebudayaan Republik Indonesia.

Rogers, E. M. (2010). Diffusion of innovations. Simon and Schuster.

Sa'ud, U. S. (2011). Inonasi Pendidikan. Alfabeta.

Sugiyono, P. (2011). Metodologi penelitian kuantitatif kualitatif dan R\&D. Alpabeta, Bandung.

Sugiyono, P. D. (2010). Statistika untuk penelitian. Bandung: Alfabeta.

Terry, G. R. (1971). Principles of management.

Zubaedi, M. A. (2015). Desain Pendidikan Karakter. Prenada Media.

Undang-Undang Sisdiknas Nomer 20 tahun 2003 pasal 3 tentang pendidikan karakter 